Article

\title{
Sugar Beet Root Yield and Quality with Leaf Seasonal Dynamics in Relation to Planting Densities and Nitrogen Fertilization
}

\author{
Ivana Varga ${ }^{1, * \mathbb{D}}$, Zdenko Lončarić ${ }^{1}$, Suzana Kristek ${ }^{1}$, Antonela Markulj Kulundžić ${ }^{2} \mathbb{D}$, Andrijana Rebekić ${ }^{1}$ \\ and Manda Antunović ${ }^{1}$ \\ 1 Faculty of Agrobiotechnical Sciences Osijek, University of Josip Juraj Strossmayer in Osijek, \\ Vladimira Preloga 1, 31000 Osijek, Croatia; zloncaric@fazos.hr (Z.L.); skristek@fazos.hr (S.K.); \\ andrijana.rebekic@fazos.hr (A.R.); manda.antunovic@fazos.hr (M.A.) \\ 2 Agricultural Institute Osijek, Južno predgrađe 17, 31000 Osijek, Croatia; antonela.markulj@poljinos.hr \\ * Correspondence: ivana.varga@fazos.hr; Tel.: +385-31-55-49-11; Fax: +385-31-554-853
}

check for updates

Citation: Varga, I.; Lončarić, Z.; Kristek, S.; Kulundžić, A.M.; Rebekić, A.; Antunović, M. Sugar Beet Root Yield and Quality with Leaf Seasonal Dynamics in Relation to Planting Densities and Nitrogen Fertilization. Agriculture 2021, 11, 407. https:// doi.org/10.3390/agriculture11050407

Academic Editor: Andreas S

Pacholski

Received: 13 March 2021

Accepted: 29 April 2021

Published: 2 May 2021

Publisher's Note: MDPI stays neutral with regard to jurisdictional claims in published maps and institutional affiliations.

Copyright: (c) 2021 by the authors. Licensee MDPI, Basel, Switzerland. This article is an open access article distributed under the terms and conditions of the Creative Commons Attribution (CC BY) license (https:/ / creativecommons.org/licenses/by/ $4.0 /)$.

\begin{abstract}
This study aimed to analyze the seasonal dynamics of sugar beet leaf and root yield and quality in different plant populations and the nitrogen fertilization rate. The field trials were set as four different planting densities (60,000 to 140,000 plants ha $\left.{ }^{-1}\right)$ and three different spring nitrogen fertilization rates: no fertilization, pre-sowing $\left(45 \mathrm{~kg} \mathrm{ha}^{-1} \mathrm{~N}\right)$, and pre-sowing with top dressing (99 $\mathrm{kg} \mathrm{ha}^{-1} \mathrm{~N}$ in 2014 and $85.5 \mathrm{~kg} \mathrm{ha}^{-1} \mathrm{~N}$ in 2015. The changes of leaf growth were done measuring leaf area (LA), leaf area index (LAI), specific leaf area (SLA), and leaf area ratio (LAR). The highest LAI in 2014 was determined on 30 July at 140,000 plants ha ${ }^{-1}\left(9.35 \mathrm{~m}^{2} \mathrm{~m}^{-1}\right)$ and in 2015 on 20 June at 100,000 plants ha ${ }^{-1}\left(4.83 \mathrm{~m}^{2} \mathrm{~m}^{-2}\right)$. In both years, the SLA and LAR was highest at the end of May. In relation to plant density, higher plant densities had on average the highest root yield, sucrose content, and white sugar yield. In both years, pre-sowing with top dressing spring nitrogen fertilization resulted in the highest root $\left(95.0 \mathrm{t} \mathrm{ha}^{-1}\right)$ and white sugar yield $\left(11.4 \mathrm{t} \mathrm{ha}^{-1}\right)$, whereas the highest sucrose content was after pre-sowing fertilization (14.9\%).
\end{abstract}

Keywords: LAI; nitrogen fertilization; plant density; root yield and quality; sugar beet

\section{Introduction}

Sugar beet accounts for $20 \%$ of world sugar production, while the remaining $80 \%$ of sugar produced is obtained from sugar cane [1]. The sugar content in sugar beet root is usually 13-20\% [2,3]. More than $98 \%$ of total root sugar is sucrose, and fructose and glucose are present in very small amounts [4]. In Europe, sugar beet is usually planted in early spring and harvested during October $[5,6]$.

The importance of leaf area related to sugar beet root growth and sugar yield is a generally recognized factor. Sugar beet leaves in spring sowing reach its maximum in late July and early August, while towards the end of vegetation it gradually decreases. The optimum leaf area index (LAI) for most field crops is around $3-4 \mathrm{~m}^{2} \mathrm{~m}^{-2}$ [7]. This was also the optimum LAI for sugar beet from mid-June till the end of July) [8,9]. It is very important to monitor the above ground plant parts development in vegetative growth [10]. The development of the leaves affects the productivity of photosynthesis and the sucrose storage in the root. On the one hand if the leaves are poorly developed assimilation area is smaller, on the other hand if leaves are too developed, the mutual shading of the leaves is greater. In both cases, the amount of sucrose accumulated in the root is reduced. In the conditions of reduced nitrogen supply, development of sugar beet leaves at the first growth phases grow well because beets have enough nitrogen available [11]. In the later growth phase of sugar beet, phenotypically the leaves are lighter in color, while the root lags behind in growth. Vukadinović et al. [11] point out that if the LAI value is greater 
than $5 \mathrm{~m}^{2} \mathrm{~m}^{-2}$, the lower leaf photosynthesis falls below the compensation point (where the photosynthesis-respiration ratio has a value less than one), which usually occurs in the morning and evening and such a crop is irresistible to drought and has a greater need for nutrients.

The number of plants per unit area is one of the most important factors for high yield; therefore, it has been researched for decades. The most common causes for a reduced number of plants per unit area are reduced field germination and agrotechnics such as sowing time, poor seedbed preparation, but also the destruction of plants through cultivating. There are several factors biotic (weediness, and pests attack) and abiotic factors (excessive rainfall, and drought stress) which can also reduce the plant number per unit area [12-21]. Several researchers had focus on the same subject. So, acording to Smit [22] and Smit et al. [23], the optimum sugar beet plant density in harvest time should be around 80,000 plants $\mathrm{ha}^{-1}$. Similar findings represent Bosemark [24], who points out that the optimum plant population for sugar beet is 75,000 plants $\mathrm{ha}^{-1}$, because the mutual shading of leaves is present in higher populations, sugar beet leaves grow slower and, as a result, dry matter accumulation in the root is reduced. Nowadays, the most common population density for sugar beet as a spring crop is around 90,000 and 110,000 plants ha ${ }^{-1}$ [25-29]. There is a possibility of even higher densities because newer genotypes have erect leaves that allow growth in a smaller vegetation area. It is very important to find in which density the aboveground mass will develop properly in actual field conditions [30].

Sugar beet nitrogen fertilization has an important influence on plant growth and root yield and quality. Nitrogen fertilization in most soils in Croatia is $140-160 \mathrm{~kg} \mathrm{ha}^{-1} \mathrm{~N}$ [31], whereas in Germany and most countries of the European Union satisfactory yields were achieved with amount of $120 \mathrm{~kg} \mathrm{ha}^{-1} \mathrm{~N}$ applied, or even less due to mineralization of the $\mathrm{N}$ in the soil $\left(80 \mathrm{~kg} \mathrm{ha}^{-1} \mathrm{~N}\right)$ [32]. According to Giannoulis et al. [33], increased nitrogen fertilization reduced the agronomic $\mathrm{N}$ efficiency. Excessive nitrogen fertilization results in greater canopy development. The maturation of beet root is slower, and sugar loss and invert sugar contents are increased mostly due to the higher harmful nitrogen compound in the root [34-36]. Varga et al. [37], was determined that $\mathrm{NO}_{3}{ }^{-}$intake in sugar beet petioles is less when sugar beet grows in higher plant populations $\left(100,000-140,000\right.$ plants ha $\left.^{-1}\right)$.

The study of sugar beet response at different plant populations, especially leaf growth analyses under field conditions is limited. Since in recent times there are not many studies about plant population influence on sugar beet yield and quality, this study aimed to determine the influence of different planting densities on sugar beet yield and quality and the seasonal dynamics of leaf growth. Moreover, this study includes spring nitrogen fertilization which is one of the main factors that influence on growth and final yield.

\section{Materials and Methods}

\subsection{Field Trials and Weather Conditions}

The field trials were conducted in Eastern Croatia in 2014 and 2015. The previous crop in both years was winter wheat. The hybrid Serenade, KWS, was sown on 18 March 2014 and 25 March 2015 at an inter-row spacing of $50 \mathrm{~cm}$ and four different intra-row spacing: 13,15,17, and $19 \mathrm{~cm}$. Each plot was $20 \mathrm{~m} \times 3.5 \mathrm{~m}$ wide and consisted of 6 rows of which plant samples were collected from central four rows during vegetation. The correction of plant population was made in the stage of 2-4 real leaves, so, therefore, four different planting densities were formed as follows: 60,000 (P1), 80,000 (P2), 100,000 (P3) and $140,000(P 4)$ plants ha $^{-1}$. The experiment was set up in the field as a completely randomized design (Figure 1).

The soil was slightly acid to neutral $(\mathrm{pH}<7)$ with low organic matter content $(<2 \%)$. Adequate fertilization for $\mathrm{P}\left(115 \mathrm{~kg} \mathrm{ha}^{-1}\right.$ in 2014 and $145 \mathrm{~kg} \mathrm{ha}^{-1}$ in 2015) and K (150 kg ha ${ }^{-1}$ in 2014 and $195 \mathrm{~kg} \mathrm{ha}^{-1}$ in 2015) was applied as basal. In the spring, nitrogen fertilization was applied as follows: N0-no fertilization in spring, $\mathrm{N} 1$ - pre-sowing $\left(45 \mathrm{~kg} \mathrm{ha}^{-1} \mathrm{~N}\right)$ and N2-pre-sowing $\left(45 \mathrm{~kg} \mathrm{ha}^{-1} \mathrm{~N}\right)$ with topdressing at 2-4 leaf stage 
(54 kg ha ${ }^{-1}$ in 2014 and $40.5 \mathrm{~kg} \mathrm{ha}^{-1}$ in 2015). Based on $\mathrm{N}$ min analysis in spring (Table 1), the topdressing was different in each year of the study.

$\begin{array}{llll}\text { Block 1 } & \text { Block 2 } & \text { Block 3 } & \text { Block 4 } \\ \text { N2 P1 } & \text { N2 P2 } & \text { N2 P3 } & \text { N2 P4 } \\ \text { N1 P1 } & \text { N1 P2 } & \text { N1 P3 } & \text { N1 P4 } \\ \text { N0 P1 } & \text { N0 P2 } & \text { N0 P3 } & \text { N0 P4 }\end{array}$

Figure 1. Experimental design.

Table 1. The amount of $\mathrm{N}$ min $\left(\mathrm{kg} \mathrm{ha}^{-1}\right)$ of the field trails in 2014 and in 2015.

\begin{tabular}{ccccc}
\hline & \multicolumn{3}{c}{ Soil Depth } \\
\cline { 2 - 5 } & $\mathbf{N}^{2} \mathbf{N H}_{\mathbf{4}}$ & $\mathbf{0 - 3 0} \mathbf{~ c m}$ & $\mathbf{N}-\mathbf{N H}_{\mathbf{4}}$ & $\mathbf{N}-\mathbf{N O}_{\mathbf{3}}$ \\
\cline { 2 - 5 } & 8.45 & 26.23 & 1.91 & $\mathbf{3 0} \mathbf{~}$ \\
2014 & 14.66 & 32.10 & 6.75 & 28.80 \\
2015 & & & & 28.14 \\
\hline
\end{tabular}

In both years, plant protection against weeds was done to keep the trials free of weeds, and there was no need for insecticide application. Plant protection against Cercospora beticola Sacc. was applied in both years (4 times in 2014 and 3 times in 2015).

In 2014, air temperature mean in vegetation was not very different from the longterm mean (LTM), but the total rainfall was $24 \%$ higher (Figure 2A). May of 2014 was extremely rainy with $170 \%$ higher rainfall than LTM $(61.7 \mathrm{~mm})$. In 2015 there was $14 \%$ less rainfall from March to October, as compared to LTM (Figure 2B). Air temperatures in July $\left(24.9^{\circ} \mathrm{C}\right)$ and August $\left(24.0^{\circ} \mathrm{C}\right) 2015$ were about $3{ }^{\circ} \mathrm{C}$ higher than LTM. Apart from high air temperatures, there was a lack of rainfall in 2015, especially in July when total monthly rainfall was only $9.5 \mathrm{~mm}$, which was $88.8 \%$ less than LTM $(85.1 \mathrm{~mm})$.
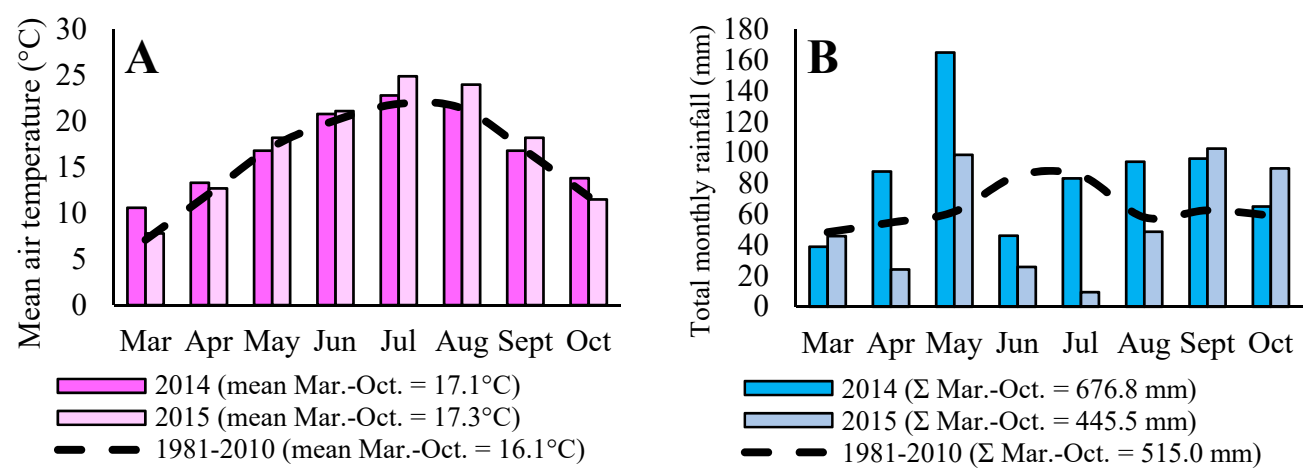

Figure 2. (A) Mean air temperature $\left({ }^{\circ} \mathrm{C}\right)$ and (B) monthly rainfall $(\mathrm{mm})$ during sugar beet vegetation (March to October) in 2014 and 2015 in comparison to the long-term mean (1981-2010) of climatological station Gradište [38].

\subsection{Plant Sampling and Growth Analysis}

The plants were sampled from each plot on twelve sampling dates at ten-day intervals from 30 May to 20 September, which were equal to 73-186 days after sowing (DAS) in 2014 and 66-179 DAS in 2015. Five representative plants per plot were taken for further analysis on each harvest date. Therefore, 720 individual plants were analyzed during the vegetation period in each year of the study. Plants were separated into storage roots (with hypocotyl) and leaves (petiole and blade). For determination of dry matter (DM), plant samples were dried in an oven at $105{ }^{\circ} \mathrm{C}$ for $48 \mathrm{~h}$.

The entire fresh leaves of sugar beet plants were separated from storage roots to determine length and width (in the widest part) of the leaf blade, which was used to 
calculate the leaf area (LA). The leaf area was calculated using a correction factor of 0.75 [39] as follows: $(1) \mathrm{A}=$ leaf blade length $(\mathrm{cm}) \times$ leaf blade width $(\mathrm{cm}) \times 0.75$. Furthermore, the leaf area index (LAI; $\mathrm{m}^{2} \mathrm{~m}^{-2}$ ), the specific leaf area (SLA; $\mathrm{m}^{2} \mathrm{~kg}^{-1} \mathrm{DM}$ leaf) and the leaf area ratio (LAR; $\mathrm{m}^{2} \mathrm{~kg}^{-1} \mathrm{DM}$ plant) were also calculated.

Sugar beet was harvested manually on 14 October 2014 and 9 October 2015, which was 205 and 213 DAS, respectively. In harvest-time, each plot had a size of $5 \mathrm{~m}^{2}$ and plants were taken in 4 replications. The sugar beet yield and quality were determined in the Sugar beet factory "Sladorana d.d. Županja" (Croatia). There were standard methods used in determination of $\alpha$-amino $\mathrm{N}, \mathrm{K}$ and $\mathrm{Na}$ in the sugar beet root [40,41]; also, sugar loss, extractable sugar, and sugar yield were determined by Buchholz et al. [42].

\subsection{Statistics}

The statistical analysis of the data was carried out using the SAS 9.4 statistical program [43]. The variance for LAI, LA, SLA, and LAR was analyzed using GLM (General linear model) procedure. The data for every year was calculated separately, but the variance between the years was not analyzed. To provide least square means differences of sugar beet yield and quality, mixed models analysis was used as nitrogen fertilization and plant density as fixed effect and repetition as random effect. The data were adjusted to Tukey. A regression model as stepwise selection was developed for each interval, predicting yields based on LAI.

\section{Results}

\subsection{Leaf Growth Analysis}

The main factors had different impact on leaf growth parameters (LA, LAI, SLA, and LAR) in both years of the trial. Depending on plant density (Figure 3a) the highest LA in 2014 was determined 143 DAS (30 July) at 60,000 plants ha ${ }^{-1}\left(7077.86 \mathrm{~cm}^{2}\right)$ and opposite to that, the lowest LA was 186 DAS (20 September) at 140,000 plants ha ${ }^{-1}\left(420.21 \mathrm{~cm}^{2}\right)$.

The highest $\left(9.35 \mathrm{~m}^{2} \mathrm{~m}^{-2}\right)$ and the lowest $\left(0.64 \mathrm{~m}^{2} \mathrm{~m}^{-2}\right)$ LAI in 2014 (Figure $3 \mathrm{c}$ ) were determined at 140,000 plants ha ${ }^{-1}$ (134 and 186 DAS, respectively).

In 2015, the plants formed smaller leaves, so the highest LA (Figure 3b) was 97 DAS (30 June) at 80,000 plants ha ${ }^{-1}\left(3867.04 \mathrm{~cm}^{2}\right)$ and the smallest 169 DAS (10 September) at 140,000 plants ha ${ }^{-1}\left(211.27 \mathrm{~cm}^{2}\right)$. The maximum LAI in 2015 (Figure 3d) was determined at 100,000 plants ha ${ }^{-1}\left(4.83 \mathrm{~m}^{2} \mathrm{~m}^{-2}\right)$, which was about 40 days earlier than 2014 . Afterwards, the LAI gradually decreased until 10 September $\left(0.90 \mathrm{~m}^{2} \mathrm{~m}^{-2}\right)$. In both years, nitrogen fertilization had a positive influence on LA and LAI.

The SLA (Figure 3e,f) and LAR (Figure 3g,h) in both years were the highest at the end of May $\left(8.61 \mathrm{~m}^{2} \mathrm{~kg}^{-1}\right.$ in 2014 and $9.98 \mathrm{~m}^{2} \mathrm{~kg}^{-1}$ in 2015 , respectively) and decreased gradually until 20 September $\left(0.17 \mathrm{~m}^{2} \mathrm{~kg}^{-1}\right.$ in 2014 and $0.31 \mathrm{~m}^{2} \mathrm{~kg}^{-1}$ in 2015 , respectively).

To determine relationship of LAI during vegetative growth to predict the root yield, regression equations were done for each plant density. Only equations which had significant $\mathrm{R}^{2}$ were shown in Table 2 .

Table 2. Regression model as stepwise selection in prediction of sugar beet root yield by LAI (average of both years).

\begin{tabular}{ccccc}
\hline Plant Density (planth ha & \\
\hline $\mathbf{1}$ & $\mathbf{R}^{\mathbf{2}}$ & $\boldsymbol{p}$ & Equation & LAI Date \\
\hline 140,000 & 0.947 & 0.001 & $\mathrm{Y}=37.401+9.095$ & 20 July \\
\hline 100,000 & 0.900 & 0.004 & $\mathrm{Y}=51.779+8.382$ & 30 June \\
\hline 80,000 & 0.835 & 0.011 & $\mathrm{Y}=20.798+10.477$ & 10 August \\
\hline 60,000 & 0.866 & 0.007 & $\mathrm{Y}=11.610+14.638$ & 30 June \\
\hline
\end{tabular}



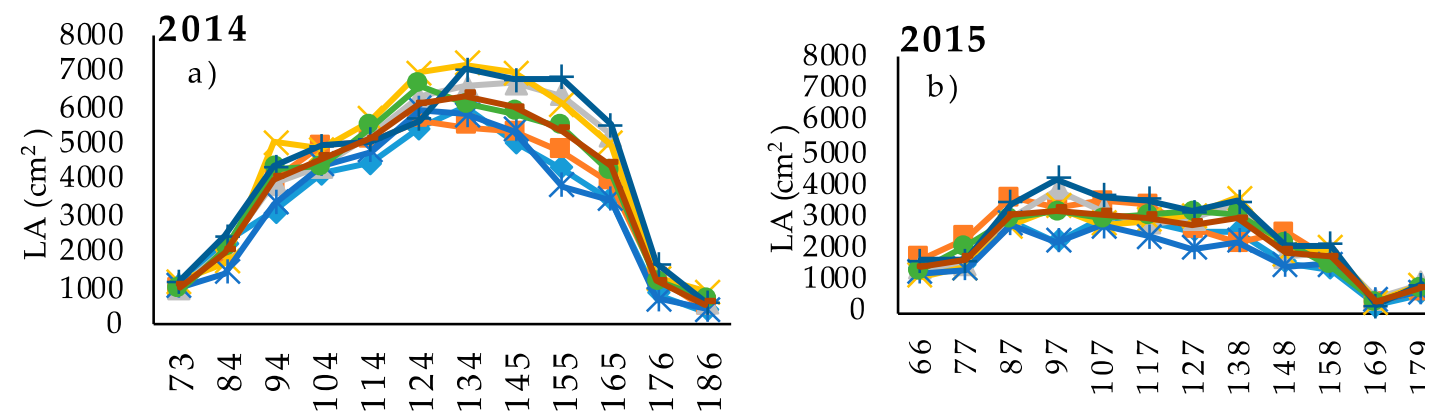

ANOVA: Date (D) ${ }^{* * *}$; Plant $(\mathrm{P})^{* * *}$; Nitrogen $(\mathrm{N})^{* * *}$; DxP ***; DxN ${ }^{* * *}$; PxN ns; DxNxP ***

ANOVA: Date (D) ${ }^{* * *}$; Plant $(\mathrm{P})^{* * *}$; Nitrogen $(\mathrm{N})^{* * *}$; $\mathrm{DxP}^{* * *}$ DxN ${ }^{* * *}$ PxN ns; DxNxP ***
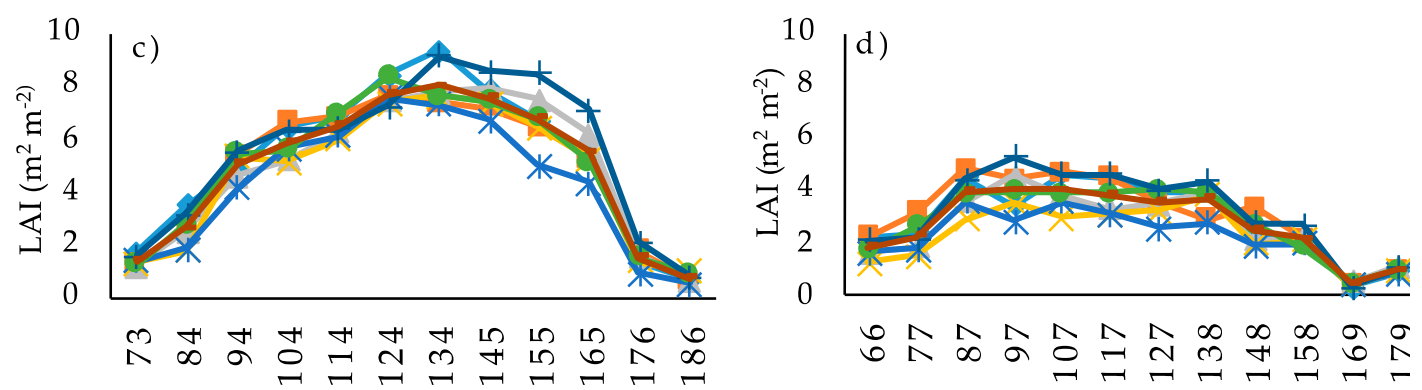

ANOVA: Date (D) $)^{* * *}$; Plant $(\mathrm{P})^{* * *}$; Nitrogen $(\mathrm{N})^{* *} ; \mathrm{DxP}$ ***; $\mathrm{DxN}^{* * *} ; \mathrm{PxN}^{*} ; \mathrm{DxNxP}^{* * *}$

ANOVA: Date (D) ${ }^{* * *}$; Plant $(\mathrm{P})^{* * *}$; Nitrogen $(\mathrm{N})^{* * *}$; $\mathrm{DxP}^{* * *} ; \mathrm{DxN}^{* * *} ; \mathrm{PxN}$ ns; DxNxP ***
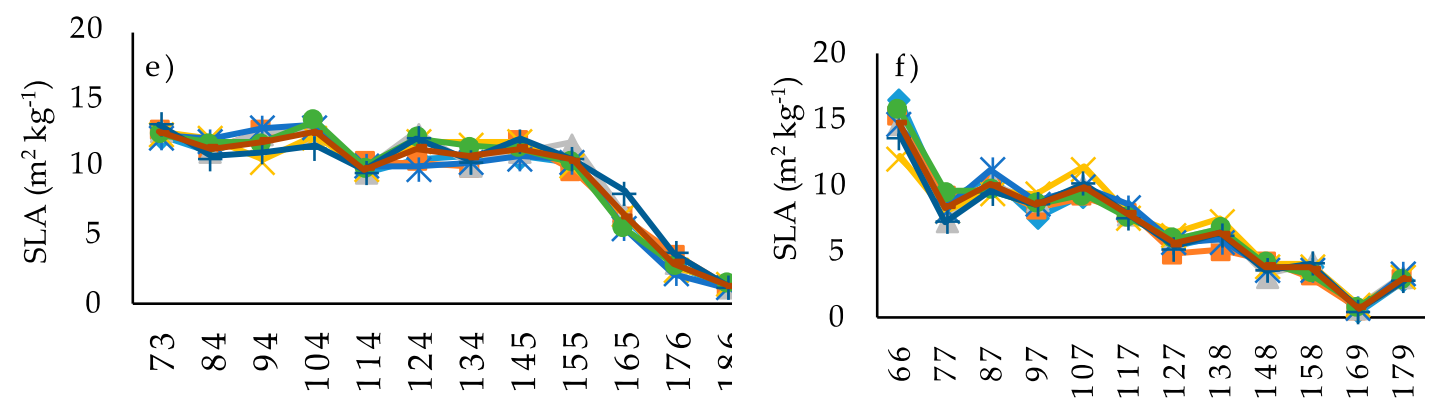

ANOVA: Date (D) ${ }^{* * *}$; Plant $(\mathrm{P}) \mathrm{ns}$; Nitrogen $(\mathrm{N}) \mathrm{ns}$; DxP $\mathrm{ns} ; \mathrm{DxN}^{* * *} ; \mathrm{PxN}^{*} ; \mathrm{DxNxP}^{* *}$

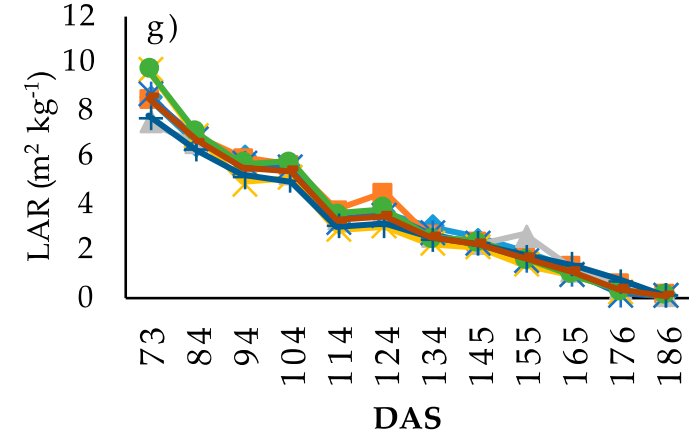

ANOVA: Date (D) ***; Plant (P) ns; Nitrogen (N) ns; DxP ns; DxN ns; PxN *; DxNxP ns
ANOVA: Date (D) ${ }^{* * *}$; Plant (P) ns; Nitrogen (N) ns; $\mathrm{DxP}^{* * *} ; \mathrm{DxN}^{* * *} ; \mathrm{PxN}^{*} ; \mathrm{DxNxP} * * *$

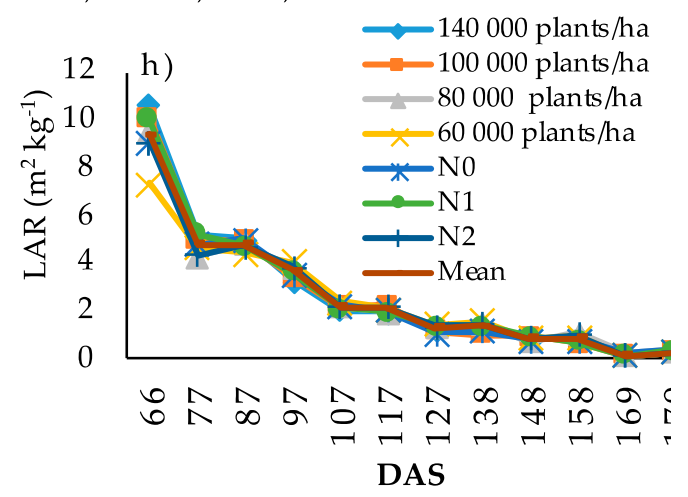

ANOVA: Date (D) ***; Plant (P) *; Nitrogen (N) ns; $\operatorname{DxP}^{* * *} ; \mathrm{DxN}^{* *} ;$ PxN ns; DxNxP ${ }^{* * *}$

Figure 3. Changes of LA (a,b), LAI (c,d), SLA $(\mathbf{e}, \mathbf{f})$, and LAR $(\mathbf{g}, \mathbf{h})$ per plant during sugar beet vegetative growth as related to different plant densities $(\mathrm{P})$ and nitrogen fertilization rate $(\mathrm{N})$ in 2014 (on the left) and 2015 (on the right). The ANOVA results refer to LA, LAI, SLA, and LAR; the levels of significance were indicated with $p<0.05\left(^{*}\right), p<0.01(* *), p<0.001\left(^{* * *}\right)$ or ns for not significant. 


\subsection{Root Yield and Quality}

Average sugar beet root yield in 2014 was $98.9 \mathrm{tha}^{-1}$, and sucrose content was $13.15 \%$, whereas in 2015 the root yield was smaller, on average $70.9 \mathrm{t} \mathrm{ha}^{-1}$ with average sucrose content of $15.50 \%$ (Tables 3 and 4). In relation to plant density, in 2014 the highest root and white sugar yield were determined at 140,000 plants ha ${ }^{-1}$ and in 2015 at 100,000 plants ha ${ }^{-1}$. Different spring nitrogen fertilization did have a significant influence on root yield and quality, as well as on the white sugar yield. In both years of the study, the highest root yield and white sugar yield were on the pre-sowing $\mathrm{N}$ fertilization with top dressing, while the highest sucrose content was at $45 \mathrm{tha}^{-1} \mathrm{~N}$.

Table 3. Sugar beet root yield, quality and sugar yield as affected by different plant densities and nitrogen fertilization rate in 2014.

\begin{tabular}{|c|c|c|c|c|c|c|c|}
\hline & & \multirow{2}{*}{$\begin{array}{l}\text { Root Yield } \\
\left(\mathrm{t} \mathrm{ha}^{-1}\right)\end{array}$} & \multirow{2}{*}{$\begin{array}{c}\text { Sucrose Content } \\
(\%)\end{array}$} & \multicolumn{3}{|c|}{$\begin{array}{c}\text { Brei Impurities } \\
\text { (mmol } 100 \mathrm{~g}^{-1} \text { beet) }\end{array}$} & \multirow{2}{*}{$\begin{array}{l}\text { White Sugar Yield } \\
\qquad\left(\mathrm{t} \mathrm{ha}^{-1}\right)\end{array}$} \\
\hline & & & & $\mathbf{K}$ & $\mathrm{Na}$ & $\alpha$-amino $\mathrm{N}$ & \\
\hline \multirow{4}{*}{$\begin{array}{l}\text { Plant density, } \\
\text { plants ha }\end{array}$} & 140,000 & 109.7 & 13.18 & 2.95 & 0.83 & 1.13 & 12.5 \\
\hline & 100,000 & 104.6 & 13.19 & 3.00 & 0.72 & 1.19 & 11.9 \\
\hline & 80,000 & 97.5 & 13.18 & 2.99 & 0.63 & 1.44 & 11.0 \\
\hline & 60,000 & 83.6 & 13.02 & 3.21 & 0.65 & 1.39 & 9.3 \\
\hline Nitrogen & 0 & 97.5 & 13.12 & 3.21 & 0.85 & 1.07 & 11.0 \\
\hline fertilization & 45 & 95.6 & 13.40 & 2.89 & 0.44 & 1.46 & 11.1 \\
\hline in spring $\left(\mathrm{kg} \mathrm{ha}^{-1}\right)$ & 99 & 103.4 & 12.91 & 3.01 & 0.84 & 1.33 & 11.4 \\
\hline Mean & & 98.9 & 13.15 & 3.04 & 0.71 & 1.29 & 11.2 \\
\hline
\end{tabular}

Mean values columns followed by different letter indicate significant difference at $p<0.01$ according to Least square means difference (Tukey adjustment); otherwise it is ns-not significant.

Table 4. Sugar beet root yield, quality, and sugar yield as affected by different plant densities and nitrogen fertilization rate in 2015.

\begin{tabular}{|c|c|c|c|c|c|c|c|}
\hline \multirow[t]{2}{*}{ Main Effect } & & \multirow{2}{*}{$\begin{array}{l}\text { Root Yield } \\
\left(t \mathrm{ha}^{-1}\right)\end{array}$} & \multirow{2}{*}{$\begin{array}{c}\text { Sucrose Content } \\
(\%)\end{array}$} & \multicolumn{3}{|c|}{$\begin{array}{c}\text { Brei Impurities } \\
\text { (mmol } 100 \mathrm{~g}^{-1} \text { beet) }\end{array}$} & \multirow{2}{*}{$\begin{array}{l}\text { White Sugar Yield } \\
\qquad\left(\mathrm{t} \mathrm{ha}^{-1}\right)\end{array}$} \\
\hline & & & & $\mathbf{K}$ & $\mathrm{Na}$ & $\alpha$-amino $\mathrm{N}$ & \\
\hline \multirow{4}{*}{$\begin{array}{l}\text { Plant density, } \\
\text { plants ha }^{-1}\end{array}$} & 140,000 & 76.1 & 15.68 & 4.19 & 0.28 & 1.28 & 10.5 \\
\hline & 100,000 & 86.1 & 15.54 & 4.37 & 0.34 & 1.50 & 11.7 \\
\hline & 80,000 & 62.2 & 15.63 & 4.29 & 0.31 & 1.38 & 8.5 \\
\hline & 60,000 & 59.1 & 15.13 & 4.24 & 0.35 & 1.43 & 7.8 \\
\hline Nitrogen & 0 & 52.6 & 14.89 & 4.21 & 0.30 & 1.18 & 6.8 \\
\hline fertilization & 45 & 73.4 & 16.30 & 4.26 & 0.24 & 1.05 & 10.6 \\
\hline in spring $\left(\mathrm{kg} \mathrm{ha}^{-1}\right)$ & 85.5 & 86.6 & 15.30 & 4.35 & 0.43 & 1.98 & 11.4 \\
\hline Mean & & 70.9 & 15.50 & 4.27 & 0.32 & 1.40 & 7.4 \\
\hline
\end{tabular}

Mean values in columns followed by different letter indicate significant difference at $p<0.01$ according to Least square means difference (Tukey adjustment); otherwise it is ns—not significant.

\section{Discussion}

This study analyses the sugar beet leaves growth in two different years from weather conditions. In our production area or Eastern Croatia, usually the most intensive leaf formation is from the beginning of June and last until mid-July. In 2014, the highest LAI was determined 134 DAS (30 July), when it averaged $7.6 \mathrm{~m}^{2} \mathrm{~m}^{-2}$, while in 2015 , the highest LAI was determined 138 DAS (10 August), when it averaged $3.5 \mathrm{~m}^{2} \mathrm{~m}^{-2}$. Such differences can be attributed to different weather conditions in 2014 and 2015. In the first period of sugar beet plant development, plants usually rely on winter moisture that remained in the soil and due to this irrigation is usually unnecessary. The lack of rainfall is common in the Eastern part of Croatia, so in some growth phases drought represent the most important limiting factor in sugar beet production. Because of the high rainfalls with moderate summer temperatures in 2014, sugar beet developed larger leaves. Therefore the average 
LAI from 114 to 155 DAS 2014 was $7.31 \mathrm{~m}^{2} \mathrm{~m}^{-2}$. In addition, even though the plant protection against fungi Cercospora beticola Sacc. in 2014 was conducted four times and in 2015 three times during the vegetation period. In both years, the treatments against Cercospora beticola Sacc. did not affect, which was obvious on the leaves. The symptoms of Cercospora beticola Sacc. was not visible only on the older leaves, but also on the middle leaves. The leaves that were affected by the fungi would gradually dry out and new leaves came out of in slammer dimensions. In addition to the achieved yield and quality (especially in 2014), it is assumed that the lack of effect of the fungicide spray was somehow reflected in the final yield in the sugar content of the root. The reduced effect of fungicide was probably due to the loss of strobilurin efficiency and low effectiveness of cyproconazole treatment [44], so the leaves were destroyed in September 2014 and 2015. In a previous study, Varga et al. [45] reported that in 2014 the highest leaf fresh weight increment of $70 \%$ was determined in June and the decrease of $30 \%$ in August. The temperature has an important influence on LAI until the end of June [46]. Hunková et al. [47] point out that in the year with a lack of precipitation in the summer months, the highest value of LAI in the phase of intensive leaf growth (30 July) was $4.05 \mathrm{~m}^{2} \mathrm{~m}^{-2}$, while in the year with higher precipitation the value of LAI at the end of July was $8.28 \mathrm{~m}^{2} \mathrm{~m}^{-2}$.

To found the relationship between leaf formation in the vegetative growth stage and yield could be beneficial for sugar beet yield improvement. Based on this study, the highest $R^{2}(0.947)$ was determined for LAI on 20 July for equation predict sugar beet root yield in 140000 plants ha ${ }^{-1}$. This confirms that in intensive leaf growth stage in mid-summer, canopy have a great influence on final sugar beet root yield.

In 2015, high air temperatures together with the lack of rainfall reflected negatively on sugar beet leaf growth, so the average LA and LAI did not increase after 10 July. Regarding weather conditions, other researchers obtained similar results. A similar LAI for sugar beet in late July of the year with a lack $\left(4.05 \mathrm{~m}^{2} \mathrm{~m}^{-2}\right)$ or excessive $\left(8.28 \mathrm{~m}^{2} \mathrm{~m}^{-2}\right)$ rain was also obtained by Hunková et al. [47] in Danube plain in Slovakia (Nitra). According to a study by Kenter and Hoffman [46] in the first half of vegetative growth for sugar beet, root development depends on the LAI, while in the second half of the vegetation, the LAI has no effect on root development. In Germany, Hadir et al. [10] measured sugar beet LAI in 2019, which was characterized as hot and dry, so plants suffered from drought and leaves were wilted. In such conditions Hadir et al. [10] found on 13 June, 10 July, and 10 September that sugar beet LAI was on average 1.62, 3.05, and $1.91 \mathrm{~m}^{2} \mathrm{~m}^{-2}$, respectively. In Greece, Tsialtas and Maslaris [48], found LAI at the beginning of July in Mediterranean climate on average $2.36 \mathrm{~m}^{2} \mathrm{~m}^{-2}$ and in milder climate $4.15 \mathrm{~m}^{2} \mathrm{~m}^{-2}$ on average. These findings confirms our result in the point of weather conditions in analysed years.

In our study, different $\mathrm{N}$ doses at fertilization had a significant influence on leaf growth for LA and LAI, but the influence was not significant for SLA and LAR (Figure 3.). In our study, the last sampling in July 2014 LAI was the highest $\left(7.6 \mathrm{~m}^{2} \mathrm{~m}^{-2}\right.$ on average) and comparing with the control treatment $\left(6.9 \mathrm{~m}^{2} \mathrm{~m}^{-2}\right) \mathrm{N}$ fertilization increased the LAI by $1.8 \mathrm{~m}^{2} \mathrm{~m}^{-2}$ with pre-sowing and by $1.5 \mathrm{~m}^{2} \mathrm{~m}^{-2}$ in pre-sowing with topdressing treatment. In 2015, the maximum LAI was achieved earlier than 2014, on 30 June $\left(3.8 \mathrm{~m}^{2} \mathrm{~m}^{-2}\right.$ on average), and pre-sowing $\mathrm{N}$ fertilization increased LAI by $1.2 \mathrm{~m}^{2} \mathrm{~m}^{-2}$ and even more, by $2.5 \mathrm{~m}^{2} \mathrm{~m}^{-2}$ in topdressing treatment, as compared to the control $\left(2.5 \mathrm{~m}^{2} \mathrm{~m}^{-2}\right)$. Tsialtas and Maslaris [49] reported that $\mathrm{N}$ rates had no significant effect on LAI, but there was a positive reaction of LAI to $\mathrm{N}$ fertilization found since the higher $\mathrm{N}$ treatments (N120, N180, and N240) had higher LAI values than the lower rates (N0, and N60). The similar findings was reported for Mekdad and Rady [50] who found that LAI at harvest time was $4.37 \mathrm{dm}^{2} \mathrm{dm}^{-2}\left(200 \mathrm{~kg} \mathrm{ha}^{-1} \mathrm{~N}\right)$ and increased with higher nitrogen fertilization to $6.41 \mathrm{dm}^{2} \mathrm{dm}^{-2}\left(350 \mathrm{~kg} \mathrm{ha}^{-1} \mathrm{~N}\right)$. In the early growth phase, sugar beet area SLA increased because leaves have less dry matter. Stephan et al. [51] and Çakmakçi et al. [52] also reported that SLA was higher in the early growth phase. 
Generally, the weather conditions in the analyzed period were different. The higher amount of rainfall in 2014 year (Figure 3) resulted with larger root formation, so the average yield was about $28 \%$ higher in 2014 (Tables 3 and 4 ).

In this study, plant density had a very significant influence on root yield and white sugar yield. Higher root and sugar yield was found with a larger number of plants per unit area $\left(100,000\right.$ and 140,000 plants ha $\left.{ }^{-1}\right)$. This was also confirmed by Çakmakçi et al. [52]. Similar results, with increasing the number of plants per unit area increases root yield, and sucrose content was proved by Söğüt and Arioğlu [53]. On the opposite, Lauer [54] did not find significant differences in sugar beet yield in relation to four different plant densities $\left(37,100\right.$ to 111,200 plants ha $\left.{ }^{-1}\right)$, even though the highest plant density had the highest sucrose content (16.3\%). For other research, the highest sugar beet root and sugar yields with planting in beds with $30 \mathrm{~cm}$ rows spacing flowed by beds with 35 and $40 \mathrm{~cm}$ rows spacing, respectively [55].

The root yield in 2014 was not affected by pre-sowing nitrogen fertilization, because field conditions were good for $\mathrm{N}$ mineralization. Hence, the root yield was even higher with the control treatment $\left(97.5 \mathrm{tha}^{-1}\right)$ than the pre-sowing $\mathrm{N}$ application $\left(95.6 \mathrm{tha}^{-1}\right)$. It is partly confirmed in an earlier study $[29,56,57]$, where the nitrogen rate's significant influence on the fresh root mass in 2014, which is in close relationship with final net to root yield, was not found. The root yield in 2015 was smaller as compared to 2014 (Tables 3 and 4), mostly due to lower rainfall. In 2015, pre-sowing with top dressing nitrogen fertilization had a greater impact on yield formation $\left(86.6 \mathrm{t} \mathrm{ha}^{-1}\right)$. Comparing the achieved yield in both years it can be concluded that the average root yield. The topdressing in phase of canopy closure is the most common practice over the Europe in sugar beet production. Based on 3-years study in Poland (Bydgoszcz), Žarski et al. [58] found that pre-sowing fertilization $\left(160 \mathrm{~kg} \mathrm{ha}^{-1} \mathrm{~N}\right)$ had on average $84.5 \mathrm{t} \mathrm{ha}^{-1}$ root yield as compared to pre-sowing with top dressing $\left(160+40 \mathrm{~kg} \mathrm{ha}^{-1} \mathrm{~N}\right)$, when root yield was on average $92.1 \mathrm{t} \mathrm{ha}^{-1}$. In both years, the sucrose content was the highest at pre-sowing $\mathrm{N}$ fertilization $\left(45 \mathrm{~kg} \mathrm{ha}^{-1}\right)$. It was confirmed that even though the agrotechnical measurements are done as recommended, still, sugar beet root yield and quality are very sensitive to weather conditions [59]. Other research had similar findings with higher $\mathrm{N}$ rate sucrose content in the root decreased [60].

\section{Conclusions}

This study aimed to determine that differences in the size of the surface area for sugar beet plant growth will affect the leaf growth and canopy development, but also relationship of leaves formation during the growing season and achieved sugar beet and yield and root quality. Moreover, the impact of spring nitrogen fertilization. To determine the sugar beet canopy development parameters as LA, LAI, SLA, and LAR, were chosen, regarding to plant populations and nitrogen fertilization in spring growing period. Generally, plants at lower plant densities $\left(60,000\right.$ and 80,000 plants ha $\left.{ }^{-1}\right)$ formed greater LA and smaller LAI, due to larger area for leaf expansion. The SLA and LAR in both years was the highest in the end of May and decreased to the September. Higher doses of $N$ fertilization increased LA and LAI but had no significant effects on SLA and LAR. The other focus of this study was to evaluate the effects of plant populations and nitrogen fertilization on sugar beet root yield and quality. The average root yield with a higher number of plants per unit area $\left(140,000\right.$ and 100,000 plants ha $\left.{ }^{-1}\right)$ was higher by $15 \%$ in 2014 and $25 \%$ in 2015 , as compared to the smaller number of plants per unit area $\left(80,000\right.$ and 60,000 plants ha $^{-1}$ ). As a possible recommendation for sugar beet production based on our research, it can be proposed that higher amounts of seeds are used in sowing, which will result in higher germination, and it may increase the final root yield per unit area as well as improve quality of the root. The highest root yield and white sugar yield in both years were determined on the highest nitrogen rate applied (pre-sowing with topdressing). In contrast, the highest sucrose content was only at pre-sowing nitrogen applications. The results on the influence of plant population in leaves growth, yield, and quality of sugar beet roots can give a 
broader picture of the optimal number of plants per unit area. So, based on our findings in harvest time, in order to achieve high yields, the number of plants per unit area should be above 100,000 plants ha $^{-1}$.

Author Contributions: Methodology, Z.L. and S.K.; samples collection I.V.; investigation I.V., A.M.K. and A.R.; writing—original draft preparation, I.V. and M.A.; visualization, A.R. All authors have read and agreed to the published version of the manuscript.

Funding: This research was part of IPA project: Enhancement of Collaboration between Science, Industry and Farmers: Technology Transfer for Integrated Pest Management (IPM) in Sugar Beet as the Way to Improve Farmer Income and Reduce Pesticide Use (contract No: IPA 2007/HR/16IPO/001040511).

Institutional Review Board Statement: Not applicable for studies not involving humans or animals. Informed Consent Statement: Not applicable.

Data Availability Statement: Not applicable.

Conflicts of Interest: The authors declare no conflict of interest.

\section{Abbreviations}

DAS—-days after sowing; LAI—leaf area index; LA—leaf area; SLA—specific leaf area; LAR—leaf area ratio.

\section{References}

1. Bruhns, J.; Baron, O.; Maier, K. Sugar Economy Europe 2013; Verlag Dr. Albert Bartens KG: Berlin, Germany, 2013.

2. Draycott, A.P.; Christenson, D.R. Nutrients for Sugar Beet Production. Soil-Plant Relationships; CABI Publishing: Oxfordshire, UK, 2003.

3. Hoffmann, C.M. Root quality of sugar beet. Sugar Tech 2010, 12, 276-287. [CrossRef]

4. Turesson, H.; Andersson, M.; Marttila, S.; Thulin, I.; Hofvander, P. Starch biosynthetic genes and enzymes are expressed and active in the absence of starch accumulation in sugar beet tap-root. BMC Plant Biol. 2014, 14, 104. [CrossRef] [PubMed]

5. Hoffmann, C.M.; Kluge-Severin, S. Growth analysis of sutumn and spring sown sugar beet. Eur. J. Agron. 2011, 34, 1-9. [CrossRef]

6. Hájková, L.; Kožnarová, V.; Možný, M.; Žalud, Z. Vliv klimatické změny na termíny setí, vzcházení a sklizně cukrové řepy. Listy Cukrov. Reparske 2020, 136, 256-261. (In Czech)

7. Roslon, E.; Boström, U.; Hansson, M. Growth dynamics in relay-cropped cereals in relation to weed competition: A greenhouse experiment. Biol. Agric. Hortic. 2005, 23, 15-28. [CrossRef]

8. Hoffmann, C.; Blomberg, M. Linking remote sensing with leaf area index of sugar beet. In Proceedings of the 1st Joint Institutional Review Board-American Society of Sugar Beet Technologists Congress, San Antonio, TX, USA, 26 February-1 March 2003; pp. 713-716.

9. Jákli, B.; Hauer Jákli, M.; Böttcher, F.; Meyer zur Müdehorst, J.; Senbayram, M.; Dittert, K. Leaf, canopy and agronomic water use efficiency of field grown sugar beet in response to potassium fertilization. J. Agron. Crop Sci. 2018, 204, 99-110. [CrossRef]

10. Hadir, S.; Gaiser, T.; Hüging, H.; Athmann, M.; Pfarr, D.; Kemper, R.; Ewert, F.; Seidel, S. Sugar beet shoot and root phenotypic plasticity to nitrogen, phosphorus, potassium and lime omission. Agriculture 2020, 11, 21. [CrossRef]

11. Vukadinović, V.; Jug, I.; Đurđević, B. Ekofiziologija Bilja; Sveučilišni Udžbenik; Neformalna Savjetodavna Služba: Osijek, Croatia, 2014. (In Croatian)

12. Jursík, M.; Holec, J.; Soukup, J.; Venclová, V. Competitive relationships between sugar beet and weeds in dependence on time of weed control. Plant Soil Environ. 2008, 54, 108-116. [CrossRef]

13. Grubišić, D.; Bažok, R.; Drmić, Z.; Kartelo, I.; Mrganić, M. Distribution of Heterodera schachtii Schmidt 1871 in the Tovarnik area and current options for control. Poljoprivreda 2016, 22, 28-33. (In Croatian) [CrossRef]

14. Baličević, R.; Ravlić, M.; Lucić, K.; Tatarević, M.; Lucić, P.; Marković, M. Allelopathic effect of Aloe vera (L.) Burm. F. on seed ger-mination and seedlings growth of cereals, industrial crops and vegetables. Poljoprivreda 2018, 24, 13-19. (In Croatian) [CrossRef]

15. Jug, D.; Jug, I.; Brozović, B.; Vukadinović, V.; Stipešević, B.; Đurđević, B. The role of conservation agriculture in mitigation and adaptation to climate change. Poljoprivreda 2018, 24, 35-44. [CrossRef]

16. Očić, V.; Grgić, Z.; Lodeta, K.B.; Šakić Bobić, B. The impact of subsidies on agricultural income in The Republic of Croatia. Poljoprivreda 2018, 24, 57-62. [CrossRef] 
17. Pačuta, V.; Rašovský, M.; Černý, I.; Michalska-Klimczak, B.; Wyszynski, Z.; Lesniewska, J.; Buday, M. Influence of weather conditions, variety and sea algae-based biopreparations on root yield, sugar content and polarized sugar yield of sugar beet. Listy Cukrov. Řepařské 2018, 134, 368-371. (In Czech)

18. Ulafić, A.; Varga, I.; Stošić, M.; Iljkić, D.; Antunović, M. Analysis of soybean growth in regard to different row-spacing. Bulg. J. Agricult. Sci. 2020, 26, 533-539.

19. Stošić, M.; Brozović, B.; Vinković, T.; Ravnjak, B.; Kluz, M.; Zebec, V. Soil resistance and bulk density under different tillage system. Poljoprivreda 2020, 26, 17-24. [CrossRef]

20. Gasparic, H.; Grubelic, M.; Uzelac, V.; Bazok, R.; Cacija, M.; Drmic, Z.; Lemic, D. Neonicotinoid residues in sugar beet plants and soil under different agro-climatic conditions. Agriculture 2020, 10, 484. [CrossRef]

21. Kristek, S.; Brkić, S.; Jović, J.; Stanković, A.; Brica, M.; Karalić, K. The application of nitrogen-fixing bacteria in order to reduce the mineral nitrogen fertilizers in sugar beet. Poljoprivreda 2020, 26, 65-71. [CrossRef]

22. Smit, A. The influence of sowing date and plant density on the decision to resow sugar beet. Field Crop. Res. 1993, 34, 159-173. [CrossRef]

23. Smit, A.B.; Struik, P.C.; Niejenhuis, J.H.; Renkema, J.A. Critical plant densities for resowing of sugar beet. J. Agron. Crop. Sci. 1996, 177, 95-99. [CrossRef]

24. Bosemark, N.O. Genetics and breeding. In The Sugar Beet Crop: Science Into Practice; Cooke, D.A., Scott, R.K., Eds.; Chapman \& Hall: New York, NY, USA, 1993; pp. 67-120.

25. Pospišil, M.; Brčić, M.; Pospišil, A.; Butorac, J.; Tot, I.; Žeravica, A. Root yield and quality of investigated sugar beet hybrids in northwest Croatia in the period from 2010 to 2013. Poljoprivreda 2016, 22, 10-16. [CrossRef]

26. Soleymani, A.; Shahrajabian, M.H. Effects of planting dates and row distance on sugar content, root yield and solar radiation absorption in sugar beet at different plant densities. Rom. Agric. Res. 2017, 34, 145-155.

27. Curcic, Z.; Ciric, M.; Nagl, N.; Taski-Ajdukovic, K. Effect of sugar beet genotype, planting and harvesting dates and their interaction on sugar yield. Front. Plant Sci. 2018, 9, 1041. [CrossRef] [PubMed]

28. Jelić, S.; Antunović, M.; Bukvić, G.; Varga, I.; Iljkić, D. Vliv hustoty porostu na růst, výnos a kvalitu cukrové řepy. Listy Cukrov. Řepařské 2019, 135, 107-111. (In Czech)

29. Varga, I.; Lončarić, Z.; Pospišil, M.; Rastija, M.; Antunović, M. Dynamics of sugar beet root, crown and leaves mass with regard to plant densities and spring nitrogen fertilization. Poljoprivreda 2020, 26, 32-39. [CrossRef]

30. Müller-Linow, M.; Pinto-Espinosa, F.; Scharr, H.; Rascher, U. The leaf angle distribution of natural plant populations: Assessing the canopy with a novel software tool. Plant Methods 2015, 11, 1-16. [CrossRef] [PubMed]

31. Pospišil, M. Ratarstvo II. Dio—Industrijsko Bilje; Zrinski: Čakovec, Croatia, 2013.

32. Marlander, B.; Hoffmann, C.; Koch, H.-J.; Ladewig, E.; Merkes, R.; Petersen, J.; Stockfisch, N. Environmental situation and yield performance of the sugar beet crop in Germany: Heading for sustainable development. J. Agron. Crop. Sci. 2003, 189, 201-226. [CrossRef]

33. Giannoulis, K.D.; Bartzialis, D.; Skoufogianni, E.; Danalatos, N.G. Assessing the efficiency of different fertilizer type and levels on maize yield. Bulg. J. Agric. Sci. 2020, 26, 167-176. [CrossRef]

34. Franzen, D.W. Delineating nitrogen management zones in a sugarbeet rotation using remote sensing-A review. J. Sugarbeet Res. 2004, 41, 47-60. [CrossRef]

35. Draycott, A.P. Sugar Beet; Blackwell Publishing Ltd.: Oxford, UK, 2006.

36. Malnou, C.; Jaggard, K.; Sparkes, D. Nitrogen fertilizer and the efficiency of the sugar beet crop in late summer. Eur. J. Agron. 2008, 28, 47-56. [CrossRef]

37. Varga, I.; Lončarić, Z.; Pospišil, M.; Rastija, M.; Antunović, M. Changes of nitrate nitrogen in sugar beet petioles fresh tissue during season with regard to nitrogen fertilization and plant population. Listy Cukrov. Řepařské 2020, 136, 198-204.

38. Croatian Meteorological and Hydrological Service. Available online: http://meteo.hr/index.php (accessed on 11 October 2019).

39. Milford, G.F.J.; Pocock, T.O.; Riley, J.; Messem, A.B. An analysis of leaf growth in sugar beet. Ann. Appl. Biol. 1985, 106, 187-203. [CrossRef]

40. ICUMSA Methods Book. Determination of $\alpha$-Amino Nitrogen in Sugar Beet by the Copper Method ('Blue Number') (Methods GS6-5); Bartens: Berlin, Germany, 2007.

41. ICUMSA Methods Book. Determination of Potassium and Sodium in Sugar Beet by Flame Photometry (Methods GS6-7); Bartens: Berlin, Germany, 2007.

42. Buchholz, K.; Märländer, B.; Puke, H.; Glattkowski, H.; Thielecke, K. Neubewertung des technischen Wertes von Zuckerrüben. Zuckerindustrie 1995, 120, 113-121. (In German)

43. SAS 9.4; SAS Institute Inc.: Cary, NC, USA, 2020.

44. Kristek, A.; Kristek, S.; Varga, I.; Drmić, Z. Results of sugar beet production depending on the hybrids selection and the number of fungicide application. Poljoprivreda 2015, 21, 15-22. [CrossRef]

45. Varga, I.; Kristek, A.; Antunović, M. Growth analysis of sugar beet in different sowing density during vegetation. Poljoprivreda 2015, 21, 28-34. [CrossRef]

46. Kenter, C.; Hoffman, C.M. Ertrags und qualitätsentwicklung von zuckerrüben in abhängigkeit von temperatur und wasserversorgung. Zuckerindustrie 2002, 127, 690-698. (In German) 
47. Hunková, E.; Krivosudská, E.; Zivcák, M. The impact of different growing years on selected sugar beet growth and yield parameters. Listy Cukrov. Řepařské 2013, 129, 330-334. (In Czech)

48. Tsialtas, J.T.; Maslaris, N. Leaf physiological traits and its relation with sugar beet cultivar success in two contrasting environments. Int. J. Plant Prod. 2012, 6, 15-36.

49. Tsialtas, J.T.; Maslaris, N. Sugar beet response to $\mathrm{N}$ fertilization as assessed by late season chlorophyll and leaf area index measurements in a semi-arid environment. Int. J. Plant Prod. 2012, 2, 57-70. [CrossRef]

50. Mekdad, A.A.A.; Rady, M.M. Response of Beta vulgaris L. to nitrogen and micronutrients in dry environment. Plant Soil Environ. 2016, 62, 23-29. [CrossRef]

51. Stephan, H.; Böttcher, U.; Kage, H. Specific leaf area development of autumn-sown sugar beet (Beta vulgaris L.) on different sowing dates in Northern Germany. J. Agric. Sci. 2015, 153, 1292-1301. [CrossRef]

52. Çakmakçi, R.; Oral, E.; Kantar, F. Root yield and quality of sugar beet (Beta vulgaris L.) in relation to plant population. J. Agron. Crop. Sci. 1998, 180, 45-52. [CrossRef]

53. Sogut, T.; Arioglu, H. Plant density and sowing date effects on sugarbeet yield and quality. J. Agron. 2004, 3, 215-218. [CrossRef]

54. Lauer, J.G. Plant density and nitrogen rate effects on sugar beet yield and quality early in harvest. Agron. J. 1995, 87, 586-591. [CrossRef]

55. Marey, S.A. Affecting each of Ridger Furrow opener parameters and planting methods on water use efficiency and sugar beet yield. Bulg. J. Agric. Sci. 2015, 21, 1304-1311. [CrossRef]

56. Varga, I.; Antunović, M.; Iljkić, D. Sugar beet root development with different nitrogen fertilization rate. Listy Cukrov. Řepařské 2017, 133, 138-141. (In Czech)

57. Jelić, S.; Lončarić, R.; Crnčan, A. Effect of Sowing Density on Economic Results of Sugar Beet Production. Listy Cukrov. Řepařské 2018, 134, 314-316. (In Czech)

58. Żarski, J.; Kuśmierek-Tomaszewska, R.; Dudek, S. Impact of irrigation and fertigation on the yield and quality of sugar beet (Beta vulgaris L.) in a moderate climate. Agronomy 2020, 10, 166. [CrossRef]

59. Černý, I.; Pačuta, V.; Ernst, D.; Zapletalová, A.; Marek, J.; Rašovský, M.; Šulík, R.; Bušo, R.; Gažo, J. Formation of yield and sugar content of sugar beet depending on soil tillage technologies. Listy Cukrov. Řepařské 2020, 136, 262-266. (In Czech)

60. Stevens, W.B.; Violett, R.D.; Skalsky, S.A.; Mesbah, A.O. Response of eight sugarbeet varieties to increasing nitrogen application: I. root, sucrose, and top yield. J. Sugarbeet Res. 2008, 45, 65-84. [CrossRef] 